\title{
Upaya Pencegahan Gangguan Postpartum Mood Sejak Kehamilan di Masa Pandemi Covid-19
}

\section{Efforts to Prevent Postpartum Mood Disorders Since Pregnancy During the Covid- 19 Pandemic}

\author{
Dwi Sri Handayani*1, Yuni Purwati ${ }^{2}$ \\ Universitas Aisyiyah Yogyakarta, Yogyakarta, Indonesia \\ *Penulis Korespondensi \\ 12dwihyani25@unisayogya.ac.id, ${ }^{2}$ yunipurwati@unisayogya.ac.id
}

Riwayat Artikel: Dikirim 2 April 2021; Diterima 4 April 2021; Diterbitkan 31 Mei 2021

\begin{abstract}
Abstrak
Covid-19 merupakan permasalahan kesehatan global saat ini. Salah satu dampak pandemi Covid-19 adalah kecemasan pada Ibu selama kehamilan dan masa nifas. Kecemasan ini dapat berisiko terjadinya gangguan postpartum mood (suasana hati pasca melahirkan). Pencegahan gangguan postpartum mood dapat dilakukan sejak masa kehamilan dengan edukasi persiapan dalam menghadapi peran ibu pada bayinya. Pelayanan kepada ibu hamil dan nifas selama masa pandemi Covid-19 dapat dilakukan dengan media komunikasi secara daring dalam upaya untuk menjaga protokol kesehatan. Tujuan pengabdian untuk mengetahui data ibu risiko gangguan postpartum mood atau depresi postpartum sejak masa kehamilan dan mempersiapkan ibu menyambut perannya sebagai ibu nifas. Metode Pengabdian dengan skrining risiko gangguan postpartum mood menggunakan Edinburgh Postnatal Depression Scale (EPDS) dan penyuluhan kesehatan tentang manajemen perawatan ibu nifas dan bayi kepada ibu hamil trimester tiga melalui media online. Hasil didapatkan sebanyak enam ibu hamil (42,86\%) tidak ada risiko depresi; tujuh ibu hamil (50\%) menunjukkan depresi mungkin dapat terjadi dan satu ibu hamil $(7,14 \%)$ menunjukkan kemungkinan depresi. Selama penyuluhan, para ibu kurang aktif dalam berdiskusi secara kelompok di media daring (online) dan terdapat beberapa ibu lebih menyukai konsultasi secara pribadi. Para ibu mengutarakan keinginan belajar materi tentang senam hamil, senam nifas dan manajemen laktasi selama kegiatan penyuluhan. Skrining gangguan postpartum mood sejak kehamilan menggunakan EPDS didapatkan adanya risiko depresi selama kehamilan dan kemungkinan risiko depresi postpartum. Penyuluhan kesehatan manajemen perawatan ibu nifas dan bayi secara daring sebagai upaya pencegahan postpartum mood sejak masa kehamilan selama pandemi covid-19 dapat dilakukan dengan metode daring.
\end{abstract}

Kata kunci: Pencegahan; postpartum mood; kehamilan; Covid-19.

\begin{abstract}
In these recent days, Covid-19 becomes the global health problem. One of the effects of the Covid-19 pandemic is a mother's anxiety during pregnancy and the puerperium. This anxiety can put mothers at risk for postpartum mood disorders. Prevention of postpartum mood disorders can be done from the pregnancy time with preparatory education in dealing with the mothers' roles for their babies. As an effort to maintain health protocols in this pandemic era, services to pregnant and postpartum women during the Covid-19 pandemic can be done through online communication media. This service aims to determine the data of the risk of postpartum mood disorders or postpartum depression since pregnancy and prepare mothers to welcome their role as postpartum mothers. The service method was carried out by screening the risk of postpartum mood disorders using the Edinburgh Postnatal Depression Scale (EPDS) and health education about the management of postpartum care for mothers and babies to the third-trimester pregnant women through online media. The results showed that six pregnant women $(42.86 \%)$ bad no risk of depression; seven pregnant women $(50 \%)$ indicated that depression might occur, and one pregnant woman $(7.14 \%)$ indicated the possibility of depression. During the counselling session, the mothers were less active in group discussions in online media and some mothers preferred private consultations. In addition, the mothers also expressed their desire to learn materials about pregnancy exercise, postpartum exercise, and lactation management during the outreach activities. From the results of screening using EPDS regarding postpartum mood disorders since pregnancy, it was found that there was a risk of depression during pregnancy and a possible risk of postpartum depression. Online health education for postpartum care management for postpartum mothers and babies as an effort to prevent postpartum mood since pregnancy during the Covid-19 pandemic can be done using the online method
\end{abstract}

Keywords: Prevention, postpartum mood, pregnancy, Covid-19. 


\section{PENDAHULUAN}

Sejak awal tahun 2020, Indonesia menghadapi permasalahan kesehatan dunia yaitu pandemi virus Covid-19. Salah satu wilayah di Indonesia yang terdampak Covid19 adalah Daerah Istimewa Yogyakarta (DIY). Pada September 2020, total kasus terkonfirmasi covid-19 di DIY sebanyak 2458 kasus dengan 29,17\% kasus dirawat, $2,60 \%$ meninggal dan 68,23\% sembuh. Sebaran kasus ini berdasarkan data di seluruh kabupaten DIY. Salah satu kabupaten terkonfirmasi kasus covid-19 adalah kabupaten Bantul (DIY, 2020).

Pandemi Covid-19 berdampak pada bidang kesehatan salah satunya pada Ibu selama kehamilan dan masa nifas. Menurut penelitian, sebanyak $75 \%$ ibu hamil dan $87 \%$ ibu nifas mengalami kecemasan ringan sampai sedang di masa pandemi Covid-19 (Yuliani \& Aini, 2020).

Salah satu upaya mempersiapkan ibu hamil sebelum menjelang masa nifas maka dibutuhkan adanya edukasi persiapan dalam menghadapi peran ibu pada bayinya sejak di masa kehamilan. Upaya ini bertujuan agar terhindar dari risiko gangguan psikologi pasca melahirkan di masa pandemi covid19. Menurut penelitian bahwa kecemasan berhubungan dengan terjadinya gangguan postpartum mood hingga postpartum depression (depresi pasca melahirkan) pada ibu (Nurbaeti et al., 2019).

Gangguan postpartum mood atau postpartum blues merupakan sindroma psikologi dan fisik yang dialami wanita satu sampai tujuh hari hingga 14 hari pertama setelah melahirkan. Pengalaman sindroma seperti gangguan mood yang serius dapat muncul gejala depresi postpartum. Gejala muncul di antaranya perasaan cemas, sedih, perasaan kesepian, tangisan, letih hingga gangguan tidur. Gejala postpartum mood dapat dialami $10 \%$ sampai 15\% ibu muda (Patel et al., 2012; Stuart \& O'Hara, 2005; Yunitasari, 2020).

Penelitian di salah satu rumah sakit Yogyakarta menunjukkan sebanyak 43,3\% ibu mengalami gangguan postpartum mood dan 10\% risiko terjadi depresi postpartum (Ernawati \& ; Merlin, 2020).

Menurut data Profil kesehatan Kabupaten Bantul Tahun 2018 bahwa angka kematian Ibu tahun 2017 (72,85 per 100 ribu) kelahiran hidup. Angka ini menurun dibanding tahun 2016 (97,65 per 100ribu). Penyebab kematian Ibu di Kabupaten Bantul tahun 2017 secara berurutan disebabkan perdarahan postpartum (17\%), dan yang lainnya disebabkan oleh hipertiroid, preeklampsia berat, syok, sepsis, peripartum, infeksi paru dan $11 \%$ disebabkan penyebab lain, salah satunya karena psikosis postpartum (DinKes, 2018).

Postpartum blues dapat terjadi karena beberapa faktor risiko seperti faktor psikologis yaitu penyesuaian diri setelah melahirkan, koping stres dan dukungan sosial. Penyesuaian diri ibu pasca melahirkan sangat dibutuhkan oleh wanita menghadapi peran baru bagi ibu (Yunitasari, 2020). Oleh karena itu, ibu membutuhkan penyesuaian diri sebelum pasca melahirkan. Penyesuaian diri dapat dimulai sejak masa kehamilan.

Gangguan postpartum mood pada ibu dapat dicegah dengan beberapa intervensi salah satunya intervensi untuk penyesuaian ibu dalam menghadapi pasca melahirkan yaitu intervensi psikososial dengan kelas antenatal yang dimulai sejak kehamilan. Topik yang dapat dibahas dalam kelas antenatal di antaranya diskusi tentang pengenalan depresi pasca melahirkan, tantangan menjadi ibu, pendidikan tentang perawatan diri, dukungan sosial dan ketrampilan dalam memecahkan masalah selama pasca persalinan (Werner et al., 2016).

Pelayanan kepada ibu hamil dan nifas selama masa pandemi Covid-19 dapat dilakukan dengan media komunikasi atau secara daring dalam upaya untuk menjaga protokol kesehatan (Kemenkes RI, 2020b). Oleh karena itu diperlukan adanya inovasi dalam promosi kesehatan pada kelompok 
berisiko Covid-19 salah satunya pada ibu hamil dan menyusui. Salah satu inovasi adalah penggunaan media daring dalam upaya meningkatkan status kesehatan ibu dalam persiapan peran merawat bayi. Menurut data wawancara di salah satu puskesmas di Yogyakarta, pada tahun 2017 tercatat satu kasus ibu nifas dengan gangguan postpartum mood. Kasus ini merupakan data ibu nifas yang dilakukan pengawasan oleh puskesmas. Berdasarkan uraian diatas maka penulis melaksanakan pengabdian masyarakat dalam upaya pencegahan gangguan postpartum mood sejak masa kehamilan menggunakan media daring di salah satu Puskesmas di Yogyakarta. Upaya pencegahan dilakukan dengan skrining risiko gangguan postpartum mood dan penyuluhan kesehatan manajemen perawatan ibu dan bayi di masa pandemi covid-19.

\section{METODE}

Pengabdian masyarakat ini dilaksankan pada bulan Oktober sampai Desember 2020. Lokasi pelaksanaan pengabdian di salah satu Puskesmas wilayah Kabupaten Bantul Yogyakarta. Kegiatan pengabdian masyarakat ini terdiri dari tahapan sebagai berikut:

\section{Tahap Persiapan}

Pengabdian masyarakat dimulai dari tahap persiapan yaitu pertama melakukan observasi dan wawancara terkait permasalahan mitra. Mitra disini adalah salah satu puskesmas di Yogyakarta. Kedua adalah perencanaan waktu dan lokasi pelaksanaan dilanjutkan perijinan di BAPPEDA Kabupaten Bantul Yogyakarta serta Puskemas tempat pengabdian masyarakat. Pengabdian masyarakat ini bertujuan untuk mengetahui data ibu risiko gangguan postpartum mood sejak masa kehamilan dan mempersiapkan ibu menyambut perannya sebagai ibu nifas. Peserta pengabdian masyarakat adalah ibu hamil trimester tiga.

\section{Tahap Pelaksanaan \\ a. Pengambilan Data Peserta}

Pengambilan data peserta secara luring (offline) di Puskesmas pada minggu ke-1 sampai ke-3 November 2020 didapatkan sebanyak $30 \mathrm{ibu}$ hamil trimester tiga. Pengambilan data peserta secara luring dilakukan dengan ketentuan protokol kesehatan menggunakan Alat Pelindung Diri (APD) level dua sesuai standar ketentuan tempat pengabdian. Pengambilan data secara luring pada gambar 1 .

\section{Gambar 1:}

Pengambilan Data Peserta Secara Oflline di Puskesmas

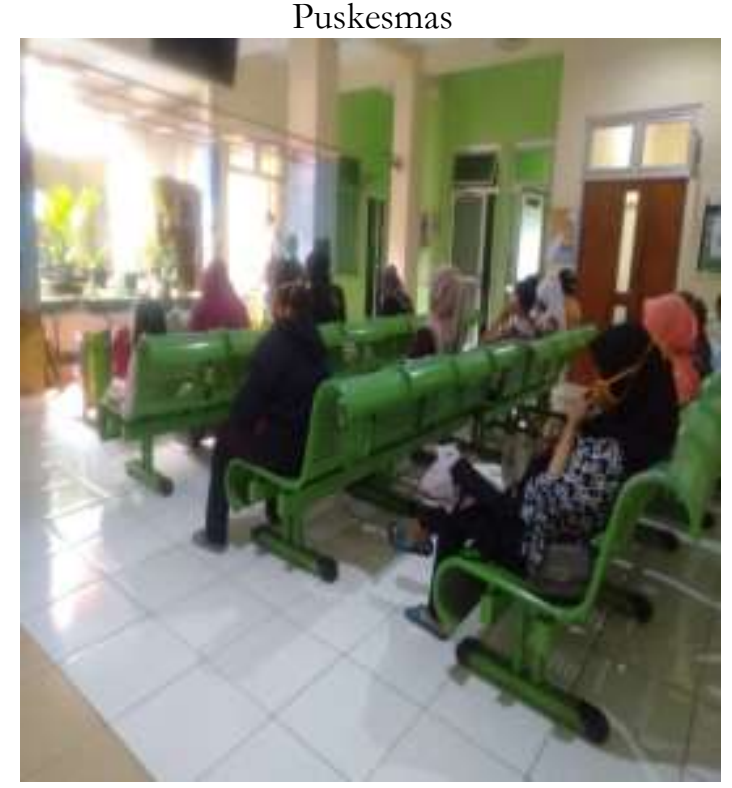

Sumber: Dokumentasi Pribadi

\section{b. Skrining Ibu Hamil dengan EPDS}

Skrining gangguan postpartum mood sejak kehamilan dilakukan secara daring pada minggu ke-1 sampai 3 bulan November 2020 menggunakan kuesioner Edinburgh Postnatal Depression Scale (EPDS) (Cox \& Holden, 2003)(Chan et al., 2014). Kuesioner EPDS sudah dialih bahasa ke bahasa Indonesia melalui Lembaga Bahasa PPB Universitas 'Aisyiyah Yogyakarta. Kuesioner dibuat secara daring menggunakan media google formulir yang terdiri dari informed concent yang berisi penjelasan tentang skrining; penyuluhan kesehatan, dan pernyataan 
kesediaan/persetujuan. Skrining dimulai dengan mengirimkan link google formulir kuesioner EPDS melalui chat whatshaap. Peserta yang bersedia mengisi kuesioner EPDS sebanyak 14 ibu hamil dari total 30 ibu hamil.

\section{Penyuluhan Kesehatan}

Penyuluhan kesehatan secara online diberikan setelah para ibu dilakukan skrining EPDS. Sebelum penyuluhan, ibu hamil dibagikan buku panduan cetak tentang "manajemen perawatan ibu nifas dan bayi" secara luring di Puskesmas. Buku panduan pada gambar 2 .

Gambar 2:

Buku Panduan Manajemen Perawatan Ibu Nifas dan Bayi

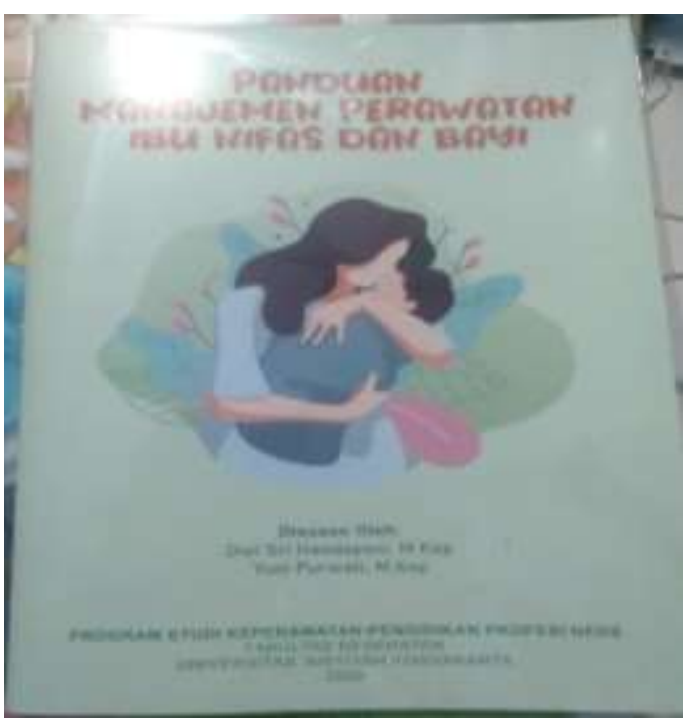

Sumber: Dokumentasi Pribadi

Buku panduan penyuluhan kesehatan berisikan materi tentang paket perawatan ibu nifas dan perawatan bayi (BlueCross BlueShield of Illinois, 2019; Clinical Guidelines - Queensland Health, 2017; Department of Health and Hongkong Physiotherapy Association, 2018; Kemenkes RI, 2020a; WHO, 2013; WHO et al., 2015; Witt et al., 2016; WNHS, 2016) pada tabel 1 .
Tabel 1:

Materi Penyuluhan Kesehatan Manajemen Perawatan Ibu Nifas dan Bayi

\begin{tabular}{|c|c|c|}
\hline No & Materi & Komponen Materi \\
\hline 1. & $\begin{array}{l}\text { Paket } \\
\text { perawatan } \\
\text { masa nifas }\end{array}$ & $\begin{array}{l}\text { Perawatan Diri (personal } \\
\text { bygiene), perawatan } \\
\text { perinieum, senam nifas, } \\
\text { perawatan payudara, } \\
\text { pemenuhan nutrisi, } \\
\text { pemenuhan seksual masa } \\
\text { nifas dan pencegahan } \\
\text { depresi postpartum }\end{array}$ \\
\hline 2. & $\begin{array}{l}\text { Paket } \\
\text { perawatan } \\
\text { bayi }\end{array}$ & $\begin{array}{l}\text { Ibu didampingi suami } \\
\text { diajarkan memandikan, } \\
\text { perawatan tali pusat, } \\
\text { mengganti pakaian, } \\
\text { menyusui, ASI eksklusif, } \\
\text { tanda bayi butuh makan } \\
\text { ASI, cara menyusui yang } \\
\text { benar, cara memerah ASI, } \\
\text { cara menyimpan ASI dan } \\
\text { imunisasi Anak }\end{array}$ \\
\hline
\end{tabular}

Penyuluhan kesehatan secara daring menggunakan media grup WhatsApp dimulai pada minggu ke-4 November sampai minggu ke-2 Desember 2020. Proses penyuluhan diawali dengan review materi buku panduan yang sudah diterima oleh peserta kemudian dilanjutkan diskusi materi yang belum dipahami dan yang ingin diketahui oleh para peserta. Materi yang di posting dalam grup WhatsApp terdiri dari gambar dan video disertai tulisan penjelasan memperdalam materi tentang manajemen perawatan ibu nifas dan bayi.

\section{Tahap Evaluasi}

Selama kegiatan penyuluhan kesehatan tentang manajemen perawatan ibu nifas dan bayi sebagai persiapan ibu dalam mempersiapkan masa nifas dilakukan evaluasi kegiatan dengan mengobservasi keaktifan peserta berdiskusi di Whatshaap group serta materi-materi yang menjadi minat peserta untuk dipelajari selama penyuluhan kesehatan. 


\section{HASIL DAN PEMBAHASAN}

Pada bulan November 2020, didapatkan peserta sebanyak 30 ibu hamil kemudian dilakukan skrining EPDS dan penyuluhan kesehatan manajemen perawatan ibu nifas dan bayi.

\section{Skrining EPDS}

Hasil skrining gangguan postpartum mood menggunakan kuesioner EPDS secara daring kepada 30 ibu hamil didapatkan sebanyak 14 ibu hamil yang bersedia mengisi kuesioner. Hasil EPDS pada tabel 2.

Tabel 2:

Distribusi Hasil Skrining EPDS Pada Ibu Hamil Trimester Tiga November $2020(n=14)$

\begin{tabular}{llcc}
\hline No & Indikator & $\begin{array}{c}\text { Kategori } \\
\text { Nilai } \\
(\text { skala })\end{array}$ & $\begin{array}{c}\text { Frekuensi } \\
(\mathrm{n}=14)(\%)\end{array}$ \\
\hline 1. & $\begin{array}{l}\text { Tidak ada risiko } \\
\text { depresi }\end{array}$ & $\leq 8$ & $6(42,86 \%)$ \\
2. & $\begin{array}{l}\text { Depresi } \\
\text { mungkin terjadi }\end{array}$ & $9-11$ & $7(50 \%)$ \\
3. & $\begin{array}{l}\text { Kemungkinan } \\
\text { depresi }\end{array}$ & $\geq 13$ & $1(7,14 \%)$ \\
\hline
\end{tabular}

Sumber: Data primer, 2020

Tabel 2 menunjukkan bahwa setalah dilakukan skrining EPDS pada 14 ibu hamil didapatkan hasil sebanyak 6 ibu hamil $(42,86 \%)$ tidak ada risiko depresi; tujuh ibu hamil (50\%) menunjukkan depresi mungkin dapat terjadi dan satu ibu hamil $(7,14 \%)$ menunjukkan kemungkinan depresi. Menurut penelitian bahwa ibu hamil selama pandemi covid-19 dilakukan pengukuran dengan EPDS diperoleh hasil 43,1\% dari 168 ibu didapatkan skor kurang dari sama dengan 13 dan sebanyak 33,1\% dari 92 ibu didapatkan skor lebih dari 13 (Durankuş \& Aksu, 2020). Menurut penelitian bahwa EPDS selain digunakan untuk skrining depresi postpartum juga dapat digunakan pada ibu hamil trimester tiga yang mana diperoleh hasil dari 714 ibu hamil sebanyak $261(36,6 \%)$ memperoleh skor 12 atau lebih (Husain et al., 2014).

\section{Penyuluhan Kesehatan Manajemen Perawatan Ibu Nifas dan Bayi}

Penyuluhan kesehatan dilakukan secara daring menggunakan media Whatshaap group pada 30 ibu hamil. Penyuluhan dengan memberikan materi berupa rangkaian tulisan, video dan gambar sesuai dengan buku panduan. Video dibuat oleh penulis dan mencari sumber lain yang berkaitan seperti video manajemen laktasi pijat oksitosin, teknik menyusui dan pijat payudara. Pada penyuluhan terdapat materi yang menjadi minat peserta untuk dipelajari menggunakan media video audiovisual meliputi senam nifas, teknik menyusui yang benar dan reflek oksitosin yang meliputi membersihkan puting, pijat payudara dalam upaya mencegah bendungan ASI serta pijat oksitosin. Berikut aktifitas penyuluhan menggunakan media Whatshaap group seperti pada gambar 3, 4 dan 5 .

Gambar 3:

Materi Senam Nifas

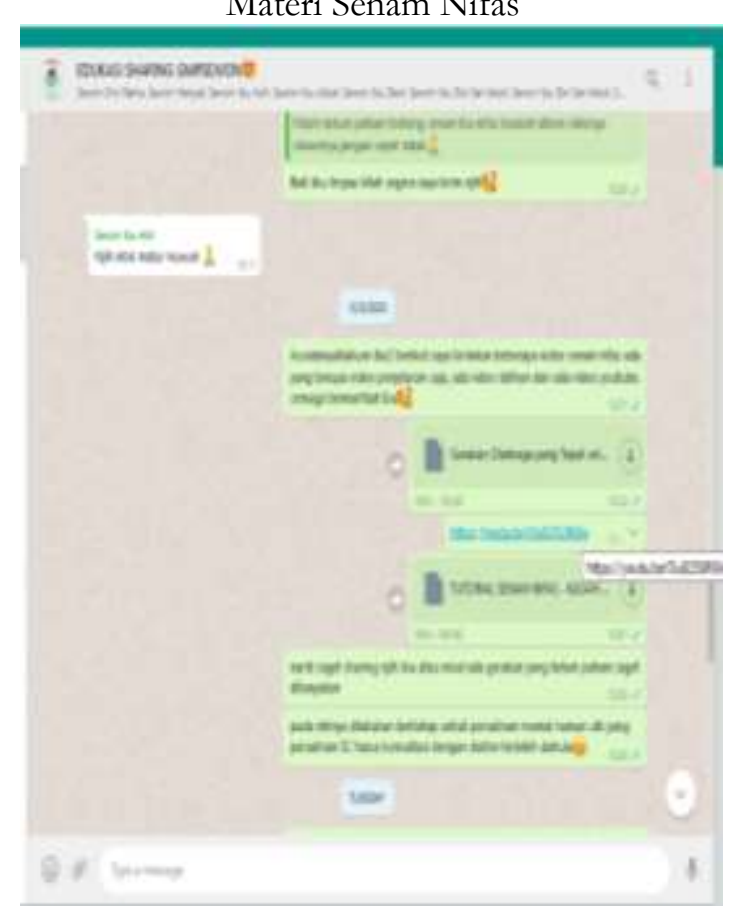

Sumber: Dokumentasi Pribadi 
Gambar 4:

Materi Teknik Menyusui Yang Benar

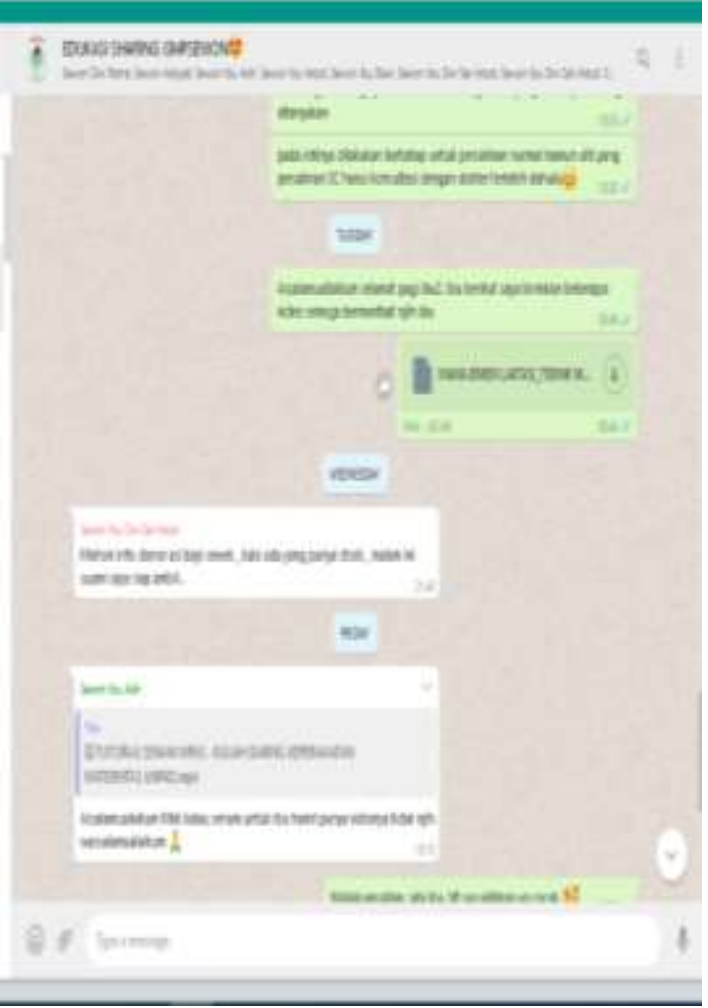

Sumber: Dokumentasi Pribadi

Gambar 5:

Reklek Oksitosin

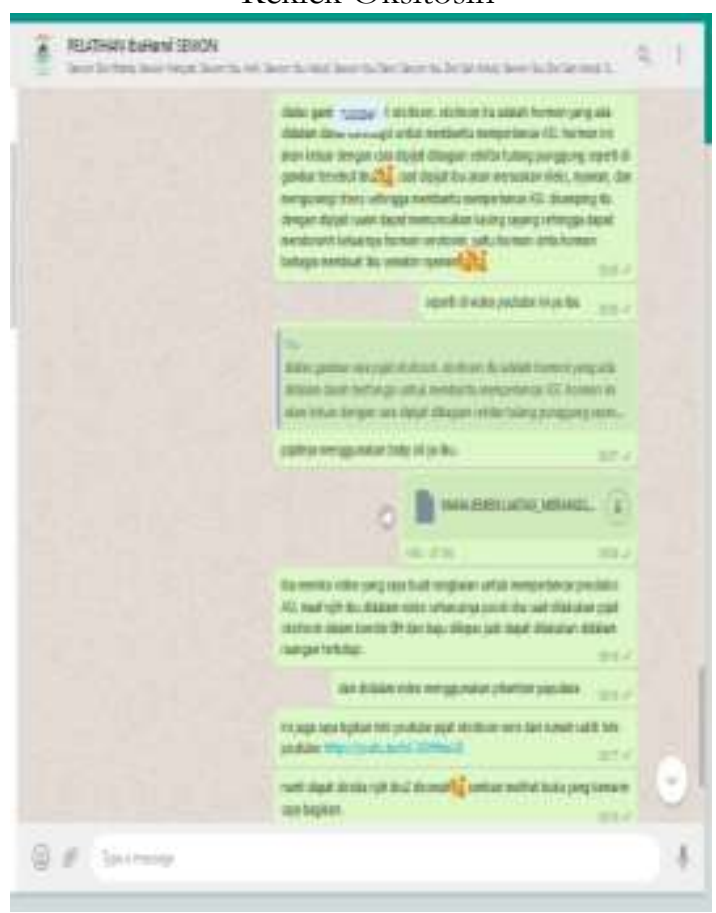

Sumber: Dokumentasi Pribadi
Selama proses penyuluhan, ada peserta konsultasi secara pribadi melalui chat WhatsApp di antaranya tentang permasalahan yang dialami di saat kehamilan dan perawatan bayi, yaitu:

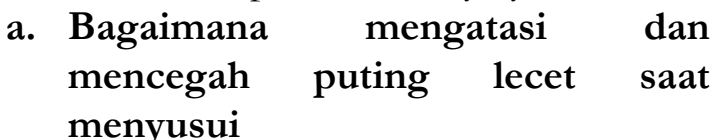

"mau sekedar bertanya bun...kalo puting lecet saat menyusui cara mengatasinya gimana ya bun... (chat pribadi WhatsApp peserta)"

\section{b. Leukhorea/keputihan kehamilan \\ selama}

"mau tanya nich kak...beberapa hari ini kok saya keputihan lumayan banyak..dan gatal...apakah punya solusi kak... (chat pribadi Whats App peserta)"

\section{c. Caries gigi pada masa kehamilan}

"siang mbk...mau tanya kalo obat sakit gigi yang aman buat ibu hamil ada nggak ya... misal cabut gigi atau tambal gigi apakah aman buat bumil (chat pribadi Whats App peserta)"

\section{d. Cara mengatasi lendir saluran} pernapasan pada bayi.

"bun mau tanya kalo si dedek saluran nafasnya kaya yang ada lendir gitu jadi kalo nyusu bunyi kaya ngorok....bayi lahir 2 minggu lalu bun (chat pribadi Whats App peserta)"

Hasil evaluasi selama penyuluhan, peserta lebih banyak mengutarakan keinginan materi seperti senam hamil, senam nifas dan manajemen laktasi. Selama penyuluhan, peserta kurang aktif berdiskusi di grup WhatsApp. Beberapa peserta lebih cenderung berkonsultasi secara Whats $A p p$ pribadi daripada berdiskusi di grup WhatsApp. Berdasarkan studi protokol penelitian, upaya menurunkan depresi selama kehamilan dan postpartum dengan menggunakan program Mindfulness-Based Childbirth and Parenting (MBCP) yaitu program berbasis perhatian dan kasih sayang diterapkan pada wanita hamil dan pasangannya untuk mengurangi gejala depresi selama kehamilan dan pasca persalinan. Program ini dalam upaya meningkatkan kesadaran ibu dan pasangan. 
Program ini terdapat kegiatan pendidikan persalinan yang gratis ditujukan kepada ibu hamil trimester 3 dan pasangan selama 16 jam meliputi materi tentang kehamilan, persalinan, nifas, menyusui, dan perawatan bayi yang baru lahir (Sacristan-Martin et al., 2019). Menurut Penelitian, hasil wawancara terhadap pasien dan caregiver bahwa hambatan utama selama menggunakan portal daring adalah keamanan, kurang ketrampilan atau rasa minat terhadap teknologi dan memilih pilihan komunikasi secara langsung (Tieu et al., 2015). Peserta menghadapi tantangan dalam membaca dan mengetik (Tieu et al., 2015).

\section{KESIMPULAN}

Skrining gangguan postpartum mood sejak kehamilan menggunakan EPDS didapatkan adanya risiko depresi selama kehamilan dan kemungkinan risiko postpartum (depresi pasca melahirkan). Penyuluhan kesehatan manajemen perawatan diri ibu dan bayi dalam upaya pencegahan gangguan postpartum mood dilakukan sejak masa kehamilan trimester tiga dapat dilakukan dengan metode daring terutama di masa pandemi Covid-19. Selama penyuluhan perlu memperhatikan kemampuan dan keaktifan peserta dalam akses materi daring sehingga perlu mempertimbangkan strategi blended method (metode daring dan luring) dengan menerapkan protokol kesehatan. Penggunaan media buku cetak yang diberikan sebelum penyuluhan kesehatan daring akan membantu dalam proses pemahaman materi oleh kelompok peserta ibu hamil.

\section{DAFTAR PUSTAKA}

BlueCross BlueShield of Illinois. (2019). Perinatal Care Guidelines 2018-2019 Perinatal Care Guidelines 2018-2019. A Division of Health Care Service Corporation, a Mutual Legal Reserve Company, an Independent Licensee of the Blue Cross and Blue Shield Association.
Chan, E. K. H., Zumbo, B. D., Zhang, W., Chen, M. Y., Darmawanti, I., \& Mulyana, O. P. (2014). Validity and Validation in Social, Behavioral, and Health Sciences. Validity and Validation in Social, Behavioral, and Health Sciences, 54(February 2016), 243-255. https://doi.org/10.1007/978-3-31907794-9

Clinical Guidelines - Queensland Health, Q. (2017). Maternity and Neonatal Clinical Guideline. Queensland Health, 1-39. www.health.qld.gov.au/qcg\%0Awww. health.qld.gov.au/qcg\%0Awww.health .qld.gov.au/qcg. Accessed June, 2020.

Cox, J., \& Holden, J. (2003). The Edinburgh Postnatal Depression Scale:" Authors' reply. The British Journal of Psychiatry, 182(4), 368. http://ovidsp.ovid.com/ovidweb.cgi? $\mathrm{T}=\mathrm{JS} \& \mathrm{PAGE}=$ reference $\& \mathrm{D}=$ psyc $4 \&$ NEWS $=$ N\&AN $=2003-03470-030$

Department of Health and Hongkong Physiotherapy Association. (2018). Postnatal Exercise (pp. 1-14). Department of Health and Hongkong Physiotherapy Association.

DinKes, B. (2018). Profil Kesehatan Pemerintah Kabupaten Bantul Tahun 2018. In Dinas Kesehatan Bantul. Dinas Kesehatan Bantul. http://dinkes.bantulkab.go.id/filestora ge/dokumen/2018/05/Profil

Kesehatan 2018.pdf

DIY, P. D. (2020). Data Terkait Covid-19 di DI. Yogyakarta. https://corona.jogjaprov.go.id/datastatistik

Durankuş, F., \& Aksu, E. (2020). Effects of the COVID-19 pandemic on anxiety and depressive symptoms in pregnant women : a preliminary study. The Journal of Maternal-Fetal \& Neonatal Medicine, $O(0), \quad 1-7$. https://doi.org/10.1080/14767058.20 20.1763946

Ernawati, D., \& ; Merlin, W. O. I. (2020). Kejadian Postpartum Blues pada Ibu 
Postpartum di RS PKU Muhammadiyah Yogyakarta. Jurnal Ners Dan Kebidanan, 7(2), 2013-2212. https://doi.org/10.26699/jnk.v7i2.AR T.p203-212

Husain, N., Husain, M., Khan, S., \& Vyas, A. (2014). Detecting Depression in Pregnancy: Validation of EPDS in British Pakistani Detecting Depression in Pregnancy: Validation of EPDS in British Pakistani Mothers. January. https://doi.org/10.1007/s10903-0149981-2

Kemenkes RI. (2020a). Pedoman Bagi Ibu Hamil, Ibu Nifas dan Bayi Baru Lahir Selama Social Distancing. \, 16.

Kemenkes RI. (2020b). Pedoman pelayanan antenatal, persalinan, nifas, dan bayi baru labir di Era Adaptasi Baru.

Nurbaeti, I., Deoisres, W., \& Hengudomsub, P. (2019). Association between psychosocial factors and postpartum depression in South Jakarta, Indonesia. Sexual and Reproductive Healthcare, 20(February), 72-76.

https://doi.org/10.1016/j.srhc.2019.0 2.004

Patel, M., Bailey, R. K., Jabeen, S., Ali, S., Barker, N. C., \& Osiezagha, K. (2012). Postpartum depression: A review. Journal of Health Care for the Poor and Underserved, 23(2), 534-542. https://doi.org/10.1353/hpu.2012.00 37

Sacristan-Martin, O., Santed, M. A., GarciaCampayo, J., Duncan, L. G., Bardacke, N., Fernandez-Alonso, C., GarciaSacristan, G., Garcia-Sacristan, D., Barcelo-Soler, A., \& Montero-Marin, J. (2019). A mindfulness and compassion-based program applied to pregnant women and their partners to decrease depression symptoms during pregnancy and postpartum: Study protocol for a randomized controlled trial. Trials, 20(1), 1-15. https://doi.org/10.1186/s13063-019- $3739-z$

Stuart, S., \& O'Hara, M. W. (2005). Postpartum depression. Psychiatric Annals, 35(7), 530-531. https://doi.org/10.3928/0048-571320050701-04

Tieu, L., Sarkar, U., Schillinger, D., Ralston, J. D., Ratanawongsa, N., Pasick, R., \& Lyles, C. R. (2015). Barriers and facilitators to online portal use among patients and caregivers in a safety net health care system: A qualitative study. Journal of Medical Internet Research, 17(12). https://doi.org/10.2196/jmir.4847

Werner, E., Miller, M., Osborne, L. M., Kuzava, S., \& Monk, C. (2016). Prevención Depresión postparto.Revisión. Archives of Women's Mental Health, 18(1), 41-60. https://doi.org/10.1007/s00737-0140475-y.Preventing

WHO. (2013). Postnatal care of the mother and newborn 2013. World Health Organization, 1-72. http://apps.who.int/iris/bitstream/10 665/97603/1/9789241506649_eng.pd $\mathrm{f}$

WHO, UNICEF, \& UNFPA. (2015). Integrated Management of Pregnancy and Childbirth: Pregnancy, Childbirth, Postpartum and Newborn Care (A Guide for Essential Practice). World Health Organization. http://dx.doi.org/10.1016/j.cirp.2016. 06.001\%0Ahttp://dx.doi.org/10.1016 /j.powtec.2016.12.055\%0Ahttps://doi .org/10.1016/j.ijfatigue.2019.02.006\% 0Ahttps://doi.org/10.1016/j.matlet.2 019.04.024\%0Ahttps://doi.org/10.10 16/j.matlet.2019.127252\%0Ahttp://d x.doi.o

Witt, A. M., Bolman, M., Kredit, S., \& Vanic, A. (2016). Therapeutic Breast Massage in Lactation for the Management of Engorgement, Plugged Ducts, and Mastitis. Journal of Human Lactation, 32(1), 123-131. https://doi.org/10.1177/0890334415 


\section{9}

WNHS. (2016). Breastfeeding and Breast Care (11th ed.). Women and Newborn Health Service.

Yuliani, D R dan Aini, N. F. (2020). Kecemasan Ibu Hamil dan Ibu Nifas Pada Masa Pandemi Covid-19 di Kecemasan Baturraden. Jurnal Sains Kebidanan, 2(2).

Yunitasari, E. ; S. (2020). Post partum blues; Sebuah tinjauan literatur. Wellness and Healthy Magazine, 2(2), 303-307. https://wellness.journalpress.id/welln ess/article/view/v1i218wh 